DOI 10.23859/2587-8352-2017-1-4-2

UDC 94 (470.316) '1917'

\author{
Sergey Holyaev \\ Candidate of Historical Sciences, Associate Professor \\ of Yaroslavl State Technical University \\ Yaroslavl, Russia \\ Holyaevsv@ystu.ru
}

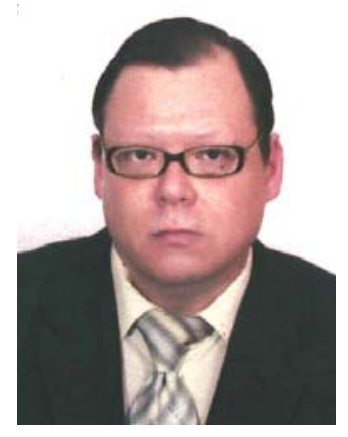

\title{
The year of 1917 in Yaroslavl
}

Abstract. The example of Yaroslavl shows the mutual influence of the events taking place at the capital level and in the provinces, on the course of the revolution. The main problem in the year 1917 was the split of the central and regional authorities. It is significant that it occurred in the first days of the revolution, when the power structures were headed by the representatives of one camp only - the liberal one. The failure of the Russian Provisional Government to recognize the primacy of the Committees for Public Security, which were influential at the local level, led to disobedience of the entire regional administration system to the government. The arrival of the Bolsheviks to power prevented the collapse of the country, once again providing support to the central government from the most provincial cities, including Yaroslavl.

Keywords: 1917, Yaroslavl, cadets, the Socialist-Revolutionaries, the Mensheviks, the Bolsheviks, the Committees for Public Security

\section{Introduction}

The revolutionary events of 1917 cannot be reviewed without considering the deep contradiction of the revolution, which manifested itself in the split of the central and regional power. The Soviet historiography did not recognize this conflict, adding purely mechanically the governmental authorities formed at the provincial level in February 1917 to the local apparatus of the Provisional Government ${ }^{1}$. The first to question this approach was V.I. Startsev in his monograph 'Domestic Policy of the First Provisional Government' devoted to the analysis of two initial months of the Provisional Government. In his opinion, the provincial authorities in 1917 did not pass into the category of the local governmental authorities, and the Provisional Government in the regions did not have its own apparatus: the local government acted autonomously and independently from it. Even the provincial and district commissars,

1 Mincz I.I. The History of the Great October. In 3 vol. V. 1. P. 715. 
the only official government representatives, were nominated from the local public and were more closely associated with it than with the centre ${ }^{2}$.

G.A. Gerasimenko provided more details regarding this conclusion at the turn of the 1980-90s in two monographs on the situation with zemstvos in 1917 and the policy of the main bodies of power in the pre-October revolution period - the Committees for Public Safety $(\mathrm{KOB})^{3}$. The facts collected by him confirmed that very soon, i.e. in the spring - in March-April 1917, the Provisional Government lost control over the processes that took place in the regions, and an intensive process of its disintegration began in the country. The regional aspects of revolutionary shock of the year 1917 were reflected in a few generalizing works of foreign researchers ${ }^{4}$. In particular we note the famous specialist in Russian history D.J. Raleigh, studied in detail the political struggle in 1917 in Saratov and other Volga cities ${ }^{5}$.

The course of the revolution in Yaroslavl province was first studied by the local publishing houses of the Ispart Commission. These were the commissions created in the early 1920s in each province and consisted of the famous Bolsheviks who collected materials on the history of the October Revolution and the Russian Communist Party. The Istpart Commission published collections of articles not only about the Bolsheviks but also about the other parties. Such was the collection 'Rybinsk in the Revolution of $1917-22^{6}$. However, essays on the history of the CPSU left a much greater trace in the historiography of regional aspects of the revolution ${ }^{7}$. They undoubtedly played a positive role in the study of 1917 at the local level, as they summarized all the information known at the time.

Among the researchers involved in the studying of regional structures of the known political parties were the works of G.P. Annin and V.P. Fedyuk. G.P. Annin specialized in the research of the Bolshevik Party, whereas V.P. Fedyuk was interest-

2 Starcev V.I. Domestic Policies of the Provisional Government of the First Election. Leningrad,1980. P. 182.

Gerasimenko G.A. Territorial Self-government in Russia. Moscow, 1990. 262 p. Idem. The First Act of Democracy in Russia. Moscow, 1992. 350 p.

${ }^{4}$ Fitzpatrick Sh.The Russian Revolution/ Oxford, 2008; Wade R.A. The Russian Revolution, 1917 Cambridge, 2000.

${ }^{5}$ Raleigh D.J. Revolution on the Volga: 1917 in Saratov. Cornell University Press, 1986. 375 p.; Raleigh D.J. Revolutionary Politics in Provincial Russia: The Tsaritsyn "Republic" in 1917. Slavic Review, 1981, vol. 40 no. 2, pp. 194-209; Raleigh D.J. The Revolution of 1917 and the Establishment of Soviet Power in Saratov. Politics and Society in Provincial Russia: Saratov, 15901917. Ohio State University Press, 1989, pp. 277-306.

${ }^{6}$ Rybinsk in the Revolution of 1917-1922. Rybinsk, 1922.

${ }^{7}$ Essays on the History of the Yaroslavl Organization of the Communist Party. 1883-1937. Yaroslavl, 1985. 
ed in the cadets. The main work of Annin 'The Bolsheviks of the Upper Volga in $1917^{8}$ devoted to the analysis of the organizational condition of the party in the Upper Volga, the process of creating social-democratic organizations united with the Mensheviks with replacement of the latter from the region later, the struggle for centralization of the party. The $\mathrm{PhD}$ thesis of V.P. Fedyuk studied various aspects of cadet activities ${ }^{9}$. Its conclusions run as follows that in 1917, the Cadet Party turned into a purely urban one, and its party organizations were almost not preserved in the countryside. Most of the party members lived in provincial centres and several parish cities. In this situation, the cadets could not stand against the Socialists. This conclusion is confirmed by the foreign historiography ${ }^{10}$.

The book 'The Struggle for the Power of the Soviets in Yaroslavl Province' stands out from the similar works on the local history during the Soviet period ${ }^{11}$. Its main value is the underlying fact that it provides more details regarding the actions of the Socialist-Revolutionaries and Mensheviks in the Upper Volga region.

In the post-Soviet period, there appeared plenty of works studying the activities of the individual parties on the territory of Yaroslavl province ${ }^{12}$ or those of specific public authorities ${ }^{13}$. However, the topic that is of interest to us is confrontation of the leading Russian parties struggling for predominance, the dominance in the key public authorities (KOBs, zemstvos, city councils and the Soviets), which remains relevant and continues to arouse interest among the researchers.

\section{Main body}

Yaroslavl occupied an important geopolitical position in the centre of the country, between the two capitals - St. Petersburg and Moscow - and the events that took place there had impact on the whole country. Thus, it was in 1917 that such an interaction occurred already in the first days of the revolution: The Provisional Government was in a state of conflict with the regional authorities, including Yaroslavl.

The new regional and provincial authorities that were formed in February-March during the days of the revolution initially expressed their unanimous and decisive support for the newly formed Provisional Government. These authorities, the public

${ }^{8}$ Annin G.P. The Bolsheviks of the Upper Volga Region in 1917. Yaroslavl, 1983. 143 p.

9 Fedyuk V.P. The Collapse of Cadet Policy in 1917 (on the Materials of Upper Volga Region): PhD dissertation in Historical Sciences. Yaroslavl, 1984. 191 p.

${ }^{10}$ Rosenberg W.G. Liberals in the Revolution: The Constitutional Democratic Party, 19171921.Princeton, 1974.

${ }^{11}$ Kozlov P.I., Rezvyy N.I. The Struggle for the Soviet Power in Yaroslavl Province. Yaroslavl, 1957. $259 \mathrm{p}$.

12 Tikhomirov N.V. Party of Socialist Revolutionaries in 1917-1918 (on the Materials of the Upper Volga Provinces): PhD dissertation in Historical Sciences. Yaroslavl, 2001. 231 p.

13 Burova A. Y. The Executive Committee of Public Organizations and Development of Alternatives to the Revolution of 1917 (on the Materials of Vladimir, Kostroma and Yaroslavl Provinces): PhD dissertation in Historical Sciences. Ivanovo, 2006. 255 p. 
security committees (KOBs), which at that time enjoyed great authority among the population, could significantly increase the influence of the Provisional Government on the general political processes taking place in Russia. They asked for only one thing from the central government to reward their loyalty: to make them an integral part of the new political system. They voluntarily expressed their desire to become government agencies in the region, thus the government could create an extensive network of its authorities. But it allowed a fatal miscalculation by not responding to the requests of the provincial committees, preferring to rely on the traditional structures of power - zemstvos and city dumas (town councils) situated closer to it. This was not surprising, as the chairman of the government - Prince G.E. Lvov - was a descendant from this environment; he headed the All-Russian Zemsky Union.

Chairmen of provincial zemstvo councils were appointed as new leaders of the provinces and provincial commissioners. The government did not only ignore the requests of the KOBs but also limited them as much as possible and cancelled all their rights. The liquidation of the KOBs did not take place, but they were not related to the official political system, and they never became its part. They were denied the main thing: financing their activities from the centre. The unjust command of the centre embittered the KOBs, and the large part of them refused to follow Petrograd's instructions. In Yaroslavl, the cadet K.K. Chernosvitov did not obey the government's decree, being elected as a provincial commissar exactly on the day of sending the government telegram to the regions, i. e. on $5^{\text {th }}$ March. The KOB in Yaroslavl province adopted a resolution per which "the order of the central government ... means the first moment of anarchy, when the old provincial power had already collapsed, and the local public had not made any arrangements to accept this power yet. This order was somewhat belated for the Yaroslavl province. The Executive Committee has already elected its Commissioner" ${ }^{\prime 4}$.

The essence of the dispute was not in who would be the commissioner, but to whom he should obey: The Provisional Government or the relevant KOB? The Provisional Government assumed that the commissar was obligated to report entirely to the government. The KOBs now disagreed even "on the same responsibility of the Commissioner, both to the central government and to the local Executive Committee" (which was among other things the wording of Yaroslavl provincial committee) ${ }^{15}$.

The Provisional Government could not prevent the election of commissars by introducing a registration system in the relevant committees (autonomous, independent of the authorities' instructions) and on 20-23rd March officially authorized the election of commissioners from the persons "enjoying confidence of the local population" ". At the same time, having satisfied the insistent demands of the province for the election of commissioners in the regions, the government did not restore the con-

\footnotetext{
${ }^{14}$ Golos [The Voice] (Yaroslavl).1917. 8 March.

15 Ibid. 16 March.

${ }^{16}$ Gerasimenko G.A. Territorial Self-government in Russia. Moscow, 1990. P.70.
} 
trol over the entire country. The provincial committees became autonomous, independent of the government, since at that moment they were funded from the local funds, whereas the commissioners were regarded as mere executors of the local will.

The idea of making the commissioners responsible to the government was not justified: they were completely dependent on the KOBs. The very committees, the actual local authorities, were outside the control of the centre. The situation was complicated by the fact that all other local authorities (zemstvos, town councils and all kinds of the Soviets) were not even formally controlled by the government. It was believed that they expressed the interests of the local population. Thus, the centre could no longer influence the local life. From that moment on, in every province, including Yaroslavl, the authorities who did not even think about the regional separatism, i.e. leaving Russia, became independent of the government, and it had no longer any levers of influence over the local life. The process of provincialization of Russia began: the country was divided into separate provinces. The situation in each province henceforth depended solely on the arrangement of political forces developing there.

In such a difficult period for Yaroslavl province, the responsibility for preserving political stability fell on the cadets; where they took key posts in the executive system. The provincial commissioner was still K.K. Chernosvitov. D.G. Timrot was elected chairman of Yaroslavl provincial KOB; previously he was chairman of provincial zemstvo council. V.N. Krylov became the third comrade (deputy) chairman of the provincial KOB. The influence of the cadets at the city level in Yaroslavl was quite strong. V.S. Lopatin was the city head (mayor) of Yaroslavl, V.N. Shiryaev chairman of the city council. N.G. Agafonov, M.P. Sakin and N.I. Sobolev were also members of Yaroslavl City Council ${ }^{17}$.

Nevertheless, it was difficult for the cadets to resist the every-day growing pressure from the people (peasants, workers and soldiers) and the more radically organized political forces-moderate and radical socialists. The pro-cadet provincial authorities in Yaroslavl were deprived of assistance not only from the central government on part of the Provisional Government, but also from the central structures of their own party.

This was quite naturally-determined for a constitutional-democratic party, the charter of which was regarded at the provincial level as a lower level of the party's authorities and specifically detailed the rights and duties only for the central and provincial committees. The provincial committees themselves were responsible for the Party's activities within the provinces. The smaller party units - those of parish (uyezd) and volost (rural) - were defined in the charter as auxiliary ones, and all the work on their development was assigned exclusively to the gubernia committees in

${ }^{17}$ State Archive of the Yaroslavl Region (GAYAO) F.137. Op. 1. D. 5318. L. 28; Golos [The Voice]. 1917. 9, 12, 19 March. 
the cadet milieu ${ }^{18}$. This approach to solving the most important organizational problems under the conditions of the revolutionary onset predetermined the future collapse of the Cadets, whose competitors, the Socialist-Revolutionaries (SRs) and the Mensheviks, acquired a large share of influence in the provincial power since the first days of the revolution.

In the committees of public security, the SRs headed several influential peasant groups. In Yaroslavl Committee, the numbers of the peasant group grew up to 30 members in March 1917. The post of the secretary of Yaroslavl Committee was assigned to I.P. Rozov. The Mensheviks A.F. Popov and I.I. Musatov became deputies chairman of Yaroslavl Province KOB. The Socialist-Revolutionary I.V. Loshadkin headed Yaroslavl district zemstvo. A large group of the Mensheviks headed by A.V. Bykov, the first chairman of Yaroslavl Soviet of Workers' Deputies, became a member of Yaroslavl City Duma ${ }^{19}$.

At the initial stage of the revolution, when the power of the Cadets was still undeniable, the moderate socialists (the Socialist-Revolutionaries and the Mensheviks) generally focused on the work in the Soviets. The Council of Peasants' Deputies was almost totally subordinated to the Socialist-Revolutionaries. The executive committee of Yaroslavl provincial council was elected at the peasants' congress held on 19-21 ${ }^{\text {st }}$ March (chairman V.A. Nogtev) ${ }^{20}$. The Mensheviks prevailed in the Soviet of Workers' Deputies. A lot of the Socialist-Revolutionaries moved to the ranks of the Soviet of Military Deputies: among them there were officers I.D. Blokhintsev, I.N. Zhirkovych; soldiers Nikiforovsky, Nifontov and Sokolov. However, Menshevik B.V. Duchen - the future provincial commissioner - was elected as chairman of the Coun$\mathrm{cil}^{21}$.

Nevertheless, the moderate socialists underestimated the importance of the Soviets themselves, in contrast to the Bolsheviks, who considered the work in the Soviets to be their main goal. The Mensheviks and the Socialist-Revolutionaries saw in the Soviets only a means to control the activities of the main bodies of power and a kind of a springboard for getting there. Within the committees of public security, under the leadership of the Soviets, certain groups representing interests of the most popular layers of the population were formed (the Soviets of Workers' Deputies were headed by working groups, the Soviets of Peasants' Deputies were headed by peasants, and the military oversaw the Soviets of Military Deputies). Most of these

18 Dumova N.G. The Cadet Party in World War I and February Revolution. Moscow, 1988. P.165.

19 GAYAO F.137. Op.1. D.5357. L.38; F. P.-180 Op.1. D.1. L.8; Golos [The Voice] 1917. 4, 24, 28, 29 March.

${ }^{20}$ Golos [The Voice]. 1917. 28 March.

21 The establishment of the Soviet power in Yaroslavl province. A Collection of Documents and Materials. Yaroslavl, 1957. P.41. The News of the Council of Military Deputies of the Yaroslavl Garrison (Yaroslavl). 1917. 19 March. 
groups were members of the relevant Soviets, although not always so. As an example, the above-mentioned peasant group consisted of ten deputies only representing Yaroslavl Council of Peasants' Deputies; the remaining 20 were chosen by the peasants directly in the volosts, at volost political meetings 22 .

Thus, the Soviets managed to increase their influence in the KOBs, which was not noticed by the liberals. This was easier because in the early days, the Soviets never went into direct conflicts with the cadet leadership of KOB. And it was not necessary - the representatives of the Soviets were the most active workers in the KOBs. The Cadets did not see any danger to themselves in strengthening of the influence of the Soviets, since they believed that the Cadets and moderate socialists were allies and had one common goal: to prevent the restoration of the old, royal power.

In the spring of 1917, the Socialist-Revolutionaries and the Mensheviks launched a broad campaign of democratization of city dumas and zemstvos in Yaroslavl province. These decisions were made by them through the KOBs, and they were put forward by those who represented the Soviets (most often workers or peasants). The meaning of 'democratization' of dumas and zemstvos referred to expulsion of rightwing parties and their representatives (those who were to the right of the Cadets) and admission of those supporting the socialist parties - especially the moderate socialists. The cutting edge of democratization on part of the local self-government authorities was not directed against the conservative circles but mainly against the Cadets. In the democratized governing authorities, the Socialist-Revolutionaries and the Mensheviks came to power.

Intervention in the work of zemstvos and dumas became of mass proportions. In the mid-May, the Yaroslavl provincial zemstvo was awaiting its turn to being democratized as the last and main stronghold of the Cadets. At the meeting of the KOB, where the question of democratization of the provincial zemstvo was discussed, the leadership of the peasant group was invited to the said zemstvo meeting included representatives of the provincial Soviets of peasants' deputies, cooperative unions and the Soviet of Workers' and Soldiers' Deputies. The Council of Soldiers' Deputies appeared in Yaroslavl in April 1917 because of the transformation of the Council of Military Deputies. The meaning of reformatting this authority consisted in depriving officers of the right to join the Council. On 8 April, the Council of Soldiers' Deputies merged with the Soviet of Workers' Deputies. Starting since that moment, the main meetings of the Soviets were held jointly, although both Councils retained their organizational independence.

The SRs demanded that six seats be allocated to the Provincial Council of Peasants' Deputies, 20 seats - to members of the district Soviets of Peasants' Deputies and four seats to cooperative unions. In addition, it was proposed that six members of the Soviet of Workers' and Soldiers' Deputies be included in the zemstvo membership. And this even though the Yaroslavl provincial zemstvo already initially con-

22 Golos [The Voice]. 1917. 24 March. 
sisted of delegates from democratized district zemstvos - there were no independent elections to the provincial zemstvo. Per the electoral procedure in effect in Russia, the provincial zemstvos consisted of representatives of district zemstvos who were delegated to district zemstvo meetings.

The Provincial Commissar Chernosvitov decided to include representatives of 'specified organizations' in the zemstvo assembly in the number required by them ${ }^{23}$. The Cadet Zemstvo government tried to challenge this decision unsuccessfully. Due to joint actions of peasant and working groups of the Yaroslavl Committee for Public Security, the pro-cadet gubernia zemstvo came under the direct control of moderate socialists.

In May-June, the Socialist-Revolutionaries and the Mensheviks occupied the leading positions in the Yaroslavl Province with great confidence. It should be noted that this situation was typical for most of the Russian provinces. Moreover, in the neighbouring provinces of Yaroslavl-Vladimir and Kostroma provinces, the success of the socialists was even more impressive. There almost all senior posts, including provincial commissioners, belonged to the SRs and the Mensheviks by the end of April - early May. In Yaroslavl, the process was slower. Thus, in the said region, the Cadet K.K. Chernosvitov left the post of provincial commissioner only on 24 August (he was succeeded by the Menshevik Dushen) ${ }^{24}$. This slow process was explained by the fact that in Yaroslavl province the cadets enjoyed greater influence. But it was impossible to resist the all-Russian tendencies, unfavourable for the Cadets, even in that region.

The tough struggle of the moderate socialists with the liberals increased chances of the Bolsheviks, the main trump card of which was centralization of the party and willingness of the lower-level party structures to obey the higher ones. In April 1917, the Bolsheviks adopted a new political program set by V.I. Lenin, who had returned from emigration in his famous "April theses". Lenin approaches has literally revolutionized the views of the Bolsheviks on the question of how the party should seize power. If before they followed the old, classical scheme, reducing itself to the fact that in order to seize power it was necessary to organize armed insurrection in the capital and then try and spread its influence over the rest of the country, the 'April Theses' worked in the opposite direction: first to seize power in the province, to strengthen positions throughout the country, and only afterwards to implement the seizure of power in the capital almost painlessly. This was precisely the profound meaning of Lenin's theses - the Party obtaining the majority of seats in the provincial Soviets, then transfer of power to the Soviets on a national scale and announcement of the Soviets as the only state institution (the "republic of the Soviets ... throughout the country, from the bottom upwards" $)^{25}$.

${ }^{23}$ GAYAO F.1527. Op. 1. D. 19. L. 8-10.

${ }^{24}$ Golos [The Voice]. 1917. 25 August.

25 Lenin V.I. Full Composition of Writings. V. 31, P. 115. 
The Bolsheviks found the weakest link in the February political system - the county government, by understanding the isolation of the provincial government from the central and provincial power structures, as well as weaknesses of the provincial uyezd ties. The Yaroslavl Bolsheviks also acted successfully on the county level. With their direct participation, the volost Soviets were organized in Uglich district, where the county Soviet of Peasants' Deputies was organized and later merged with the workers' council. The Soviet of Workers' Deputies was established in Lyubim; in Danilov, the Soviet of Workers' and Soldiers' Deputies was united with the Soviet of Peasants' Deputies. The re-election of the Soviet of Workers' Deputies was held in $\mathrm{Mologa}^{26}$. All these measures increased the influence of the Bolsheviks significantly with regards to the overall situation in Yaroslavl province.

The actions of the Yaroslavl Bolsheviks are indicative in the fact that they had to act in a difficult situation. In the Yaroslavl Soviet, there was a very strong influence of the Socialist-Revolutionaries and the Mensheviks. It was not by chance that in the first Executive Committee, the Bolsheviks received only two seats out of ten (I.I. Korotkov, F. I. Dokukin), and G.I. Petrovichev was appointed secretary of the said Executive Committee ${ }^{27}$.

Even in October 1917, the Bolsheviks were in the minority in the Yaroslavl Soviet of Workers' Deputies. On $16^{\text {th }}$ October, the first meeting of the re-elected Council of Workers' Deputies was held. The re-election of the Council was held in September, at the very time when the prestige of the Bolsheviks in the country had grown immeasurably. However, in Yaroslavl the results of the elections were quite modest: only 36 deputies out of 139 supported the Bolsheviks. The moderate socialists put through 67 of their supporters (40 Mensheviks and 27 Socialist-Revolutionaries). In the new team of the Executive Committee of the Soviet of Workers' Deputies, the Bolsheviks were also in numerical disadvantage: six out of 15 . The remaining members were five Mensheviks and four Socialist-Revolutionaries; the Menshevik I.I. Schleifer became Chairman of the Soviet ${ }^{28}$.

Nevertheless, the re-elections of the Soviets held in September brought considerable benefits to the Bolsheviks, since they had a clear advantage in the elections to the soldiers' faction of the Council. The Council of Soldiers' Deputies included 75 representatives of the Bolshevik Party (in the soldiers' faction of the Council, the Socialist-Revolutionaries had only 15 dedicated followers). Since the main meetings of the Soviets were held jointly, the Bolsheviks took the overall work of the Council under their control ${ }^{29}$.

26 Kozlov P.I., Rezvyy N.I. The Struggle for the Soviet Power in Yaroslavl Province. Yaroslavl, 1957.

27 GAYAO F. R-180. Op. 1. D. 1. L. 1.

${ }^{28}$ GAYAO F. R-180. Op. 1. D. 149a. L. 249.

${ }^{29}$ Kozlov P.I., Rezvyy N.I. The Struggle for Soviet Power in Yaroslavl Province. Yaroslavl, 1957. P. 116, 117, 134. 
In October 1917, the Bolsheviks' plan finally began to be implemented. Four Bolsheviks - D.S. Zackheim, N.F. Dobrokhotov, A.M. Dadukin and P.A. Safronov were sent from the united Yaroslavl Soviet of Workers' and Soldiers' Deputies to the second All-Russian Congress of Soviets, where the question of power was to be decided $^{30}$.

The events taking place in Petrograd and the seizure of power in the capital are usually understood as the events of October 1917. However, this is fundamentally wrong; the most important part of the coup took place in the province. The main thing in the Bolsheviks' plan was that the Bolsheviks along with the capital took power in the largest provincial and uyezd centres. The regional party committees coordinated their actions to seize power in the provinces, holding an intermediate position between the Central Committee and the provincial committees. The regional committees were responsible to the Central Committee for the development of the situation in adjacent provinces. The activities aimed at seizing power in the Upper Volga region was led by the Moscow Regional Committee.

On 14 October, the bureau of the Moscow Regional Committee announced of their intention to begin an open struggle for power, whereby responsible party workers were sent to all provincial cities and major regional centres in the area (13 provinces referred to the Moscow Regional Committee of the Russian Social-Democratic Labor Party of the Bolsheviks ${ }^{31}$ ). The couriers were given a conditional text of telegrams (individual for each city), upon receiving of which the local Bolsheviks would know that their party was taking power in Petrograd, and thus they had to start acting at their own level. The telegram intended for Yaroslavl read as follows: "The conference nobody will be". ${ }^{32}$ In Yaroslavl, M.P. Yanyshev was sent with this instruction $^{33}$.

The telegram expected from Moscow came on $25^{\text {th }}$ October at around 12 o'clock in the afternoon ${ }^{34}$. The power in Yaroslavl passed to the Bolsheviks on $27^{\text {th }}$ October. On the morning of that day, the Bolshevik faction of both Soviets (of workers and soldiers) demanded that the moderate wing held a joint meeting of the Soviets, having mentioned that in the extreme case the meeting would be held without their participation. The Mensheviks and the Socialist-Revolutionaries agreed, and in the evening the meeting was opened. Its outcome was obvious: the transfer of power to the Bolsheviks took place by 88 votes to the remaining 46. The Mensheviks and the So-

30 The Establishment of Soviet Power in Yaroslavl Province. A Collection of Documents and Materials. Yaroslavl, 1957. P. 255.

31 Serebryakova Z.L. Regional Association of Councils of Russia. March 1917 - December 1918. Moscow, 1977. P. 21-23.

${ }^{32}$ Zhokhov M. The signal of the uprising. Northern worker (Yaroslavl). 1974. Novermber, 6.

33 Annin G.P. The Bolsheviks of the Upper Volga Region in 1917. Yaroslavl, 1983. P. 109111.

${ }^{34}$ Zhokhov M. The signal of the uprising. Northern worker (Yaroslavl). 1974. Novermber, 6. 
cialist-Revolutionaries stepped down from their parliamentary powers, leaving the Soviet to full disposal of the Bolsheviks. Those who remained in the hall elected the new executive committee, consisting entirely of the Bolsheviks ${ }^{35}$.

During a quick analysis of the events that happened in the autumn of 1917, it may seem that the success of the Bolsheviks in October was predetermined. In fact, the situation was much more complicated. The Socialist-Revolutionaries and the Mensheviks had the opportunity to provide decent resistance to prevent the Bolsheviks from coming to power or at least to hamper their actions as much as possible. The moderate socialists in the autumn of 1917 still held strong positions. In Yaroslavl, the moderate socialists enjoyed the majority seats in the provincial KOB and the city duma. The Socialist-Revolutionaries had an overwhelming superiority in the provincial Council of Peasants' Deputies, and the influence of the Mensheviks was also strong in the Soviet of Workers' Deputies. The situation was similar in the other provinces, almost in entire Russia, the local government belonged to the moderate socialists. Having such levers of influence, they could provide support to the government. However, nothing seemed to have been done. It goes without saying, there was struggle against the Bolsheviks on part of the Socialist-Revolutionaries and the Mensheviks, but the resistance was maintained exceedingly formally. Why? The ruling power in the country was not just a handful of ministers who had settled themselves in the government, but on the contrary, it was centred around the moderate socialists. The October coup was not directed against the weak government, which had little effect on them, but rather against the Socialist-Revolutionaries and the Mensheviks.

The point is that this handful of liberal ministers had become an insurmountable obstacle for the Socialist-Revolutionaries and the Mensheviks on their way to the heights of power. The acting head of government A.F. Kerensky was considered a member of the Socialist-Revolutionary Party but did not have any relation to the organizational structures of the party. He believed that the Socialists were not ready to govern Russia without any aid from the liberals and sought to preserve the coalition with them. The policy of Kerensky evoked growing irritation of the SocialistRevolutionaries; the opposition was growing in the ranks of the party, towards the head of the government. When the Bolsheviks began to seize power, the SRs decided to take advantage of the situation. They did not doubt that having overthrown Kerensky, the Bolsheviks could not resist in power alone and should have entered negotiations with other socialist parties. That is why in those October days, instead of arranging effective resistance to the Bolsheviks, the SRs put forward the idea of forming a homogeneous socialist government - from the Bolsheviks to the people's socialists, i.e. representatives of all socialist parties were included in that government. The Socialist-Revolutionaries and the Mensheviks were confident that they would as-

35 GAYAO F. R-180. Op. 1. D. 149a. L. 292, 293; Kozlov P.I., Rezvyy N.I. The Struggle for Soviet Power in Yaroslavl Province. Yaroslavl, 1957. P. 141, 142-143. 
sume the leading role in the government, whereas the Bolsheviks would take auxiliary roles.

But the Bolsheviks seized power not with the view to give it immediately to the SRs. The Socialist-Revolutionaries were in the error, believing that the Bolsheviks could not hold out long in power - and, moreover, their position helped the Bolsheviks greatly. The Socialist-Revolutionaries realized that they were mistaken when it had already been too late. By the time of convocation of the Constituent Assembly, to which the Socialist-Revolutionaries had attributed their main hopes, the main levers of power in the Soviets belonged to the Bolsheviks. This allowed them to dissolve the Constituent Assembly.

\section{Conclusions}

One of the main problem of the development of the revolution of 1917 was the split of the central and provincial authorities. It is characteristic that the split took place when the development of the country was determined by the representatives of one camp (both central and provincial authorities were ruled by the liberals). The subsequent confrontation between the moderate socialists and the liberals worsened the situation even more, and in the incomplete eight months the February regime brought Russia to the brink of a national catastrophe.

In October days of 1917, the Bolsheviks did what the Provisional Government could not do: once again they united the central and the provincial authorities. The simultaneous seizure of power in the capital, Petrograd, and most provincial centres, including Yaroslavl, allowed the Bolsheviks to provide their central government, Sovnarkom, with the support of all its actions on part of the new provincial authorities.

\section{References}

1. Annin G.P. Bolsheviki Verkhnevolzhya v 1917 godu [The Bolsheviks of the Upper Volga region in 1917]. Yaroslavl: Verkhne-Volzhskoe knizhnoe izdatelstvo, 1983. 143 p. (In Russian)

2. Burova A.Yu. Ispolnitelnye komitety obshchestvennykh organizaciy $i$ alternativy razvitiya revolyucii 1917 goda (na materialakh Vladimirskoy, Kostromskoy i Yaroslavskoy guberniy): dis. ... kand. ist. nauk [Burova A.Y. The Executive Committee of Public Organizations and Development of Alternatives to the Revolution of 1917 (on the Materials of Vladimir, Kostroma and Yaroslavl Provinces): PhD dissertation in Historical Sciences]. Ivanovo, 2006. 255 p. (In Russian)

3.Dumova N.G. Kadetskaya partiya v period pervoy mirovoy voyny i Fevralskoy revolyucii [The Cadet Party in World War I and the February revolution]. Moscow: Nauka, 1988. 244 p. (In Russian)

4.Fedyuk V.P. Krakh kadetskoy politiki v 1917 godu (po materialam Verkhnego Povolzhya): dis. ... kand. ist. nauk [The Collapse of Cadet Policy in 1917 (on the Materials of Upper Volga region): PhD dissertation in Historical Sciences]. Yaroslavl, 1984. 191 p. (In Russian)

5. Gerasimenko G.A. Zemskoe samoupravlenie v Rossii [Territorial Self-government in Russia]. Moscow: Nauka, 1990. 262 p. (In Russian)

6. Gerasimenko G.A. Pervyy akt narodovlastiya v Rossii [The First Act of Democracy in Russia]. Moscow: Nika, 1992. 350 p. (In Russian) 
7. Kozlov P.I., Rezvyy N.I. Borba za vlast Sovetov v Yaroslavskoy guberniy [The Struggle for Soviet Power in Yaroslavl Province]. Yaroslavl: Knizhnoe izdatelstvo, 1957. 259 p. (In Russian)

8. Lenin V.I. O zadachakh proletariata $\mathrm{v}$ dannoy revolyucii [On the tasks of the proletariat in this revolution]. Poln. sobr. soch. [Full composition of writings]. Vol. 31, pp. 113-118. (In Russian)

9. Mincz I.I. Istoriya Velikogo Oktyabrya [The History of The Great October]. In 3 vol. V. 1]. Moscow: Nauka, 1977. 784 p. (In Russian)

10. Ocherki istorii Yaroslavskoy organizacii KPSS. 1883-1937 [Essays on the History of the Yaroslavl Organization of the Communist Party. 1883-1937]. Yaroslavl: Verkhne-Volzhskoe knizhnoe izdatelstvo, 1985. 320 p. (In Russian)

11. Rybinsk v revolyucii 1917-1922 godov [Rybinsk in the Revolution of 1917-1922]. Rybinsk: Izdatelstvo Istparta Rybinskogo gubkoma RKP (bolshevikov), 1922. 72 p. (In Russian)

12. Serebryakova Z.L. Oblastnye obedineniya Sovetov Rossii. Mart 1917 - dekabr 1918 [Regional Association of Councils in Russia. March 1917 - December 1918]. Moscow: Nauka, 1977. 232 p. (In Russian)

13. Starcev V.I. Vnutrennyaya politika Vremennogo pravitelstva pervogo sostava [Domestic Policies of the Provisional Government of the First Election]. Leningrad: Nauka, 1980. 256 p. (In Russian)

14. Tikhomirov N.V. Partiya socialistov-revolyucionerov v 1917-1918 gg. (na materialakh guberniy Verkhney Volgi): dis. ... kand. ist. nauk [Party of Socialist Revolutionaries in 1917-1918 (on the Materials of Upper Volga Provinces): PhD dissertation in Historical Sciences]. Yaroslavl, 2001. 231 p. (In Russian)

15. Zhokhov M. Signal vosstaniya [The signal of the uprising]. Severnyy rabochiy (Yaroslavl) [Northern Worker (Yaroslavl)]. 1977. $6^{\text {th }}$ November. (In Russian).

16. Fitzpatrick Sh. The Russian Revolution. Oxford, 2008. 224 p.

17. Raleigh D.J. Revolution on the Volga: 1917 in Saratov. Cornell University Press, 1986. $373 \mathrm{p}$.

18. Raleigh D.J. Revolutionary Politics in Provincial Russia: The Tsaritsyn «Republic» in 1917. Slavic Review, 1981, vol. 40, no. 2, pp. 194-209.

19. Raleigh D.J. The Revolution of 1917 and the Establishment of Soviet Power in Saratov. Politics and Society in Provincial Russia: Saratov, 1590-1917. Ohio State University Press, 1989, pp. 277-306.

20. Rosenberg W.G. Liberals in the Russian Revolution: The Constitutional Democratic Party, 1917-1921. Princeton, 1974. 534 p.

21. Wade R.A. The Russian revolution, 1917. Cambridge, etc., 2000. 337 p. 